\title{
Effect of Integrated Nutrient Management on Yield Parameters of Banana cv. Rajapuri
}

\author{
Suhasini S. Pattar ${ }^{*}$, Kulapati Hipparagi, I.B. Biradar, \\ S.N. Patil, R. Suma, Mallikarjun Awati and Arunkumar Kamble \\ Department of Fruit Science, College of Horticulture, UHS, Bagalkot-587104, \\ Karnataka, India \\ *Corresponding author
}

\begin{abstract}
A B S T R A C T
Keywords

Banana, INM,

Rajapuri,

Biofertilizer,

Azospirillum

Article Info

Accepted:

26 December 2017

Available Online:

10 January 2018

Banana (Musa spp.) is one of the important fruit crops of the tropics. The present investigation was carried out during 2016-17 in the experimental field at the College of Horticulture, Haveli, Bagalkot district, Karnataka, India. The cv. Rajapuri is the commercial variety used for the study. The objective of experiment includes to study the effect of INM on yield parameters of banana. Treatment T2 RDF100\% (200:100:300 g N: $\mathrm{P}_{2} \mathrm{O}_{5}: \mathrm{K}_{2} \mathrm{O}+20 \mathrm{~kg}$ FYM per plant) + PSB (20g)+ Azospirillum (20g) registered better yield parameters such as length of bunch, number of hands per bunch, weight of bunch, number of fingers per hand and bunch, weight of finger, length and girth of finger, yield per plant and total yield. Higher productivity in banana is possible through, proper nutritional management and other cultural practices.
\end{abstract}

\section{Introduction}

The nutrient requirement of banana is very high which is mainly exploited from a very limited soil depth due to shallow root system of the crop. There is good response from a plant which is given with combined form of nutrients than separately. Increase or decrease of one nutrients element may substantially increase or decrease the uptake of the other nutrients. Banana has a high demand for nitrogen and specifically potassium. Hence, better vegetative growth ensures better bunch development. Banana takes up more nutrients per unit area than any other crop. The high fertilization requirement of banana is mainly due to its rapid vigorous growth and high fruit yield. Combined application of inorganic fertilizers, organic manures and biofertilizers all together at a time in a sequence, during growth and developmental stages of plants, produced fruits with good quality, cost effective and eco-friendly i.e., without any adverse effects on soil health and environment. The banana cv. Rajapuri (Musa AAB) being an exhaustive crop, proper manuring and fertiliser application has to be restored for obtaining good yields. The study 
was undertaken to find out the influence of INM on quality parameters of banana.

\section{Materials and Methods}

The experiment contains six treatments and four replications laid out in a randomized complete block design. The treatments consist of $\mathrm{T}_{1}$ - RDF 100\% (200:100:300g N:P $\mathrm{O}_{5}: \mathrm{K}_{2} \mathrm{O}$ $+20 \mathrm{~kg}$ FYM per plant), $\mathrm{T}_{2}$-RDF100\% (200:100:300 g N:P $\mathrm{P}_{2}: \mathrm{K}_{2} \mathrm{O}+20 \mathrm{~kg}$ FYM per plant) + PSB (20g)+ Azospirillum (20g), $\mathrm{T}_{3}$ $\mathrm{RDF} 75 \%+25 \% \mathrm{~K}_{2} \mathrm{O}$, through organic source, $\mathrm{T}_{4}-\mathrm{RDF} 50 \%+50 \% \mathrm{~K}_{2} \mathrm{O}$, through organic source, $\mathrm{T}_{5}-\mathrm{RDF} \quad 25 \%+75 \% \quad \mathrm{~K}_{2} \mathrm{O}$, through organic source and $\mathrm{T}_{6}-100 \% \quad \mathrm{~K}_{2} \mathrm{O}$, through organics source.

Note: PSB = Phosphate Solubilizing Bacteria, $\mathrm{FYM}=$ Farm Yard Manure, $\mathrm{RDF}=$ Recommended Dose of Fertilizer, Organic sources: Vermicompost (3.0\%:1.0 \%:1.5\%), FYM (0.75\%:0.20\%:0.50\%) of $\mathrm{N}: \mathrm{P}_{2} \mathrm{O}_{5}: \mathrm{K}_{2} \mathrm{O}$ (Jithndra Singh, 2014). Organic source: Vermicompost, based on $\mathrm{K}_{2} \mathrm{O}$ requirement vermicompost is applied to different treatments.

Bunch length was measured by using meter scale from the first hand at the top up to last hand and the mean length of bunches was recorded and expressed in centimetres.

The total number of hands per bunch was counted and expressed in number. The matured bunches were harvested and the peduncle was cut, leaving $22.50 \mathrm{~cm}$ above the first hand and $5 \mathrm{~cm}$ below the last hand. Mean weight of bunches was recorded and expressed in $\mathrm{kg} /$ plant. The fingers were counted from middle hand and taken average and expressed in number. Similarly, all the fingers in a bunch were counted and expressed in number. The weight of finger was recorded immediately after harvest of the bunches and expressed in gram.
The finger length was measured from base of fruit to the tip where it is attached to the stalk and expressed in centimetres. The finger girth was measured at the middle of the finger/fruit by using a thread and expressed in centimetres. The weight of bunch harvested per plant at each harvesting was recorded and from the same, the total yield per plant was worked out and expressed in kilogram. The total yield was calculated by multiplying the yield per plant with the total number of plants per hectare and expressed in tonnes per hectare.

\section{Results and Discussion}

The data on effect of INM on bunch characters viz., length of bunch, number of hands per bunch, internodal length of bunch and weight of bunch are presented in Table 1.

The effect of INM on length of bunch is presented in Table 1. There were Significant difference on length of bunch was observed among the treatments. The maximum length of bunch $(59.40 \mathrm{~cm})$ was registered in treatment $\mathrm{T}_{2}$, where, plants were provided with RDF 100\% (200:100:300 g NPK + $20 \mathrm{~kg}$ FYM per plant $)+$ PSB (20 g) + Azospirillum $(20 \mathrm{~g})$. However, the treatment $\mathrm{T}_{6}(54.85 \mathrm{~cm})$ and $\mathrm{T}_{1}(54.40 \mathrm{~cm})$ were on par with each other, which was followed by $\mathrm{T}_{3}(53.00 \mathrm{~cm})$. The minimum length of bunch was recorded in the treatment $\mathrm{T}_{4}(52.92 \mathrm{~cm})$ and was on par with $\mathrm{T}_{5}(52.95 \mathrm{~cm})$.

The effect of INM on number of hands per bunch is presented in Table 1.There was a significant variation among the treatments with number of hands per bunch. The maximum number of hands (9.70) per bunch was recorded in treatment $\mathrm{T}_{2}$, with, plants were provided RDF 100\% (200:100:300 g NPK + $20 \mathrm{~kg}$ FYM per plant) + PSB (20 g) + Azospirillum $(20 \mathrm{~g})$, which was followed by $\mathrm{T}_{3}$ (8.45), $\mathrm{T}_{1}$ (7.95) and $\mathrm{T}_{4}$ (7.40). However the 
minimum number of hands (6.75) per bunch was recorded in treatment $\mathrm{T}_{5}$.

The data pertaining to the weight of bunch was furnished in Table 1. The weight of bunch was differed significantly among the different treatments. The maximum weight of bunch $(10.89 \mathrm{~kg})$ was recorded in $\left(\mathrm{T}_{2}\right)$, where plants were supplied with RDF 100\% (200:100:300 g NPK +20 kg FYM per plant) + PSB (20 g) + Azospirillum $(20 \mathrm{~g})$, followed by $\mathrm{T}_{3}(9.53 \mathrm{~kg})$, $\mathrm{T}_{6}(8.93 \mathrm{~kg}), \mathrm{T}_{4}(8.42 \mathrm{~kg})$ and $\mathrm{T}_{1}(7.89)$. The minimum weight of bunch $(7.52 \mathrm{~kg})$ was recorded in $\left(\mathrm{T}_{5}\right)$.

The effect of INM on internodal length between hands is presented in Table 1. There was a significant difference among the treatments in internodal length between the hands. The longest internodal length between hands $(5.04 \mathrm{~cm})$ was registered in treatment $\mathrm{T}_{1}$, where, plants were provided with RDF 100\% (200:100:300 g NPK + 20 kg FYM per plant), which was followed by $\mathrm{T}_{4}(4.94 \mathrm{~cm})$, $\mathrm{T}_{5}(4.89 \mathrm{~cm}), \mathrm{T}_{2}(4.76 \mathrm{~cm})$ and $\mathrm{T}_{6}(4.75 \mathrm{~cm})$ and were on par with each other. The shortest internodal length between hands $(4.65 \mathrm{~cm})$ was recorded in the treatment $\left(\mathrm{T}_{3}\right)$.

The finger characters such as, number of fingers per hand, finger length $(\mathrm{cm})$, finger girth $(\mathrm{cm})$ and weight of finger $(\mathrm{g})$ are presented in Table 2.

The data pertaining to number of fingers per hand is furnished in Table 2. The number of fingers per hand differed significantly among the treatments. The plants of $T_{2}$ received with RDF 100\% (200:100:300 g NPK + $20 \mathrm{~kg}$ FYM per plant $)+$ PSB $(20 \mathrm{~g})+$ Azospirillum $(20 \mathrm{~g})$ registered the maximum number of fingers per hand (14.20). However, $\mathrm{T}_{1}$ (13.60), $\mathrm{T}_{6}$ (13.55) and $\mathrm{T}_{3}$ (13.30) were on par with each other. The minimum (12.35) number of fingers were recorded in treatment $T_{5}$ and was on par with $\mathrm{T}_{4}(12.70)$.
Among the various treatments, the average weight of finger varied significantly. It could be observed from the Table 8 that, the treatment $\left(\mathrm{T}_{2}\right)$ with the application of RDF 100\% (200:100:300 g NPK + 20 kg FYM per plant $)+$ PSB $(20 \mathrm{~g})+$ Azospirillum (20 g) exhibited significantly the higher finger weight $(81.96 \mathrm{~g})$, which was followed by $\mathrm{T}_{6}$ (72.62 g).

Whereas, treatments $\mathrm{T}_{3}(68.41), \mathrm{T}_{4}(68.42)$ and $\mathrm{T}_{1}$ (69.2) were on par with each other. The minimum finger weight $(51.03 \mathrm{~g})$ was noticed in $\left(\mathrm{T}_{5}\right)$ control.

The data on the effect of INM on mean finger length of banana cv. Rajapuri presented in the Table 2 the results indicated that there were significant differences in finger length between the treatments.

The longest finger length $(13.21 \mathrm{~cm})$ was obtained in $\mathrm{T}_{2}$, where, the application of RDF 100\% (200:100:300 g NPK + 20 kg FYM per plant $)+$ PSB (20 g) + Azospirillum (20 g), which was followed by $\mathrm{T}_{3}(12.81 \mathrm{~cm})$ and $\mathrm{T}_{6}$ $(12.56 \mathrm{~cm})$. However, the treatments $\mathrm{T}_{4}(11.89$ $\mathrm{cm})$ and $\mathrm{T}_{5}(11.95 \mathrm{~cm})$ were on par with each other. Whereas, the shortest finger length $(11.82 \mathrm{~cm})$ was obtained in $\left(\mathrm{T}_{1}\right)$.

The data on mean girth of a finger was recorded after harvest. The maximum finger girth $(12.13 \mathrm{~cm})$ was observed in $T_{2}$, where, the plants received RDF 100\% (200:100:300 gm NPK + $20 \mathrm{~kg}$ FYM per plant) + PSB (20 g) + Azospirillum $(20 \mathrm{~g})$, which was followed by $\mathrm{T}_{4}(11.56 \mathrm{~cm}), \mathrm{T}_{3}(11.47 \mathrm{~cm})$ and $\mathrm{T}_{1}(11.11$ $\mathrm{cm})$. The minimum finger girth $(9.28 \mathrm{~cm})$ was recorded in $\left(\mathrm{T}_{2}\right)$, which was on par with $\mathrm{T}_{6}$ $(10.89 \mathrm{~cm})$.

The effect of INM on total yield per plant of banana cv. Rajapuri showed significant differences among the different treatments and the data on yield was presented in Table 3 . 


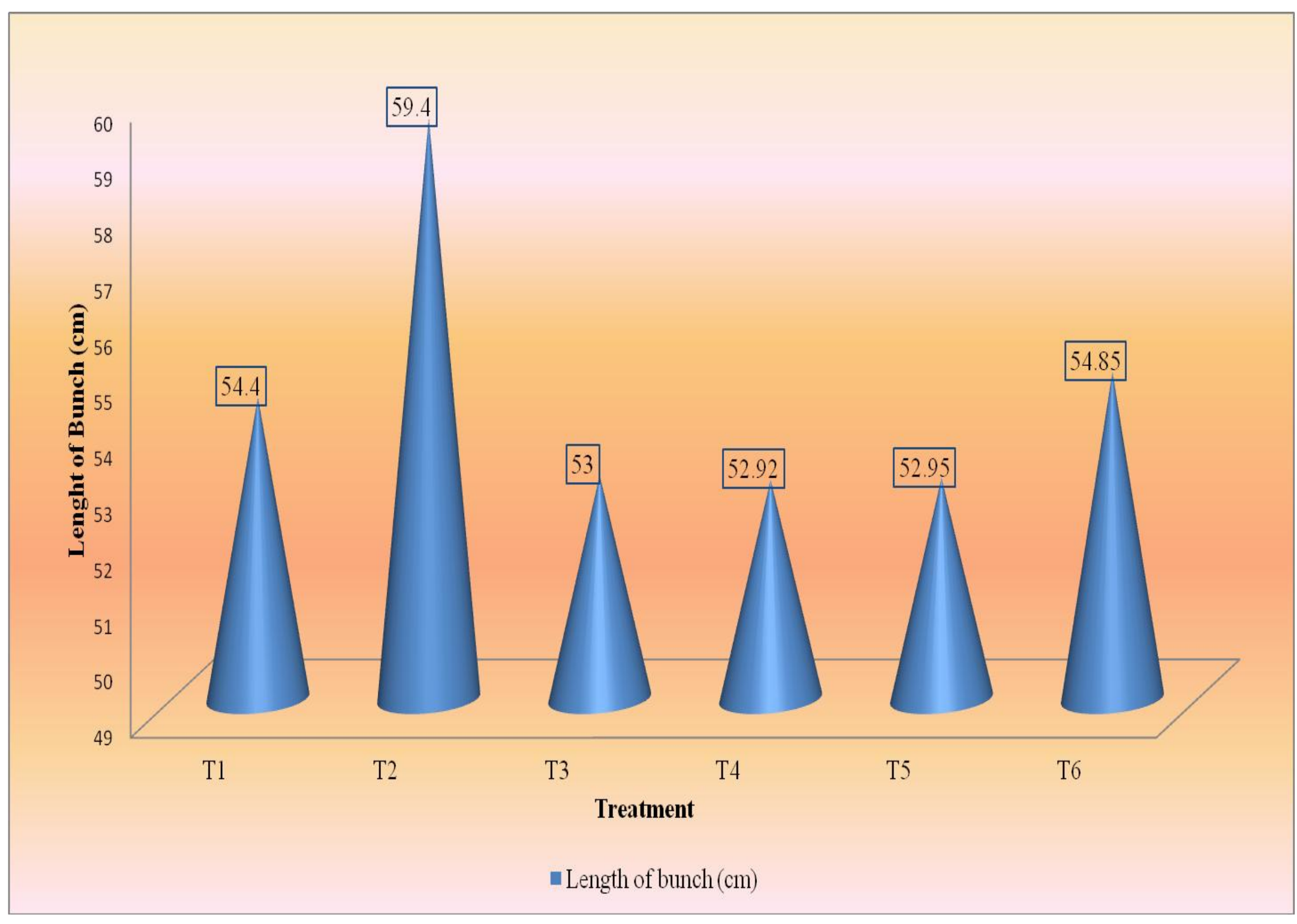


Fig.1 Effect of INM on Length of bunch in banana $c v$. Rajapuri (AAB)

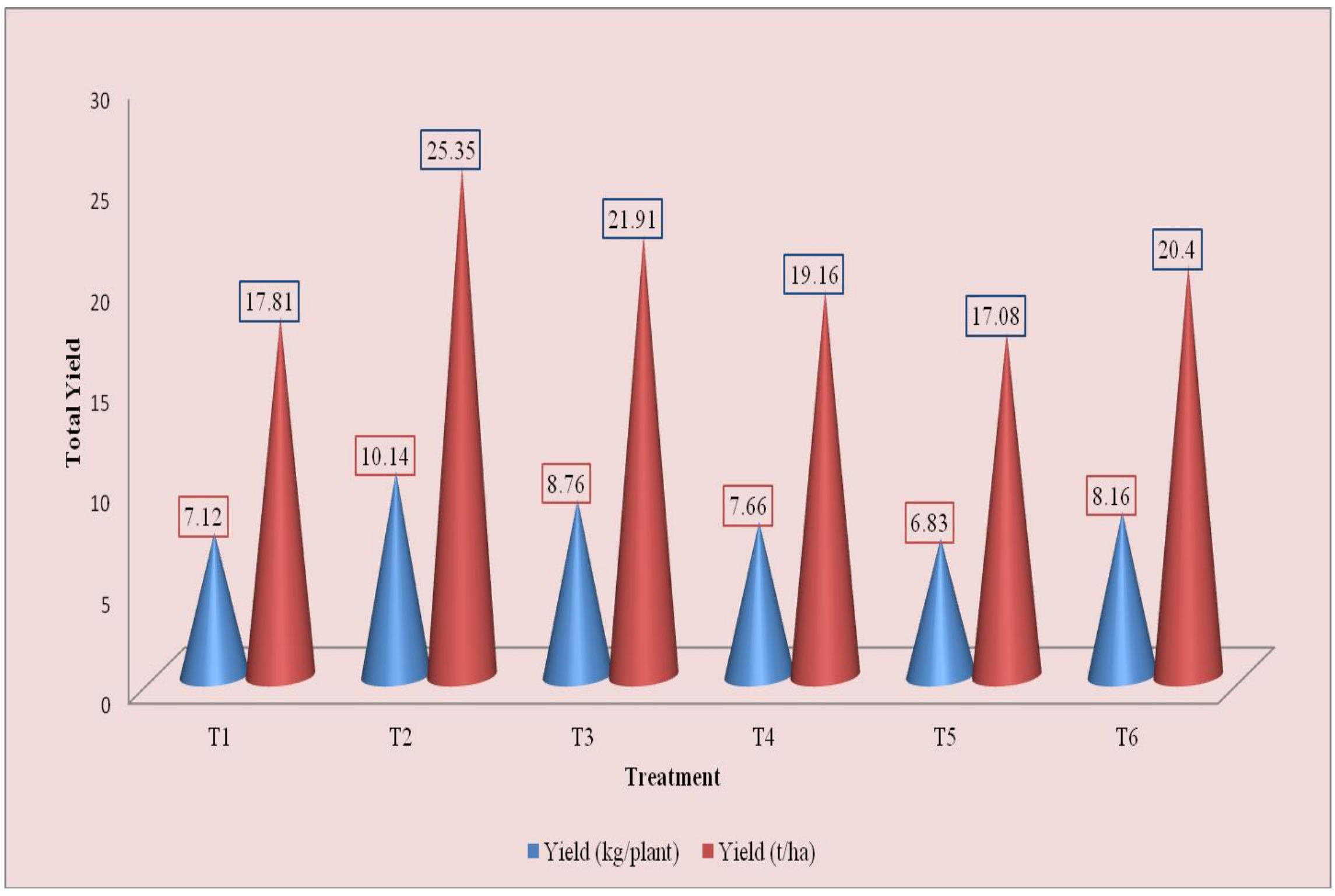


Fig.2 Effect of INM on number of hands per bunch and weight of bunch in banana $c v$. Rajapuri (AAB)

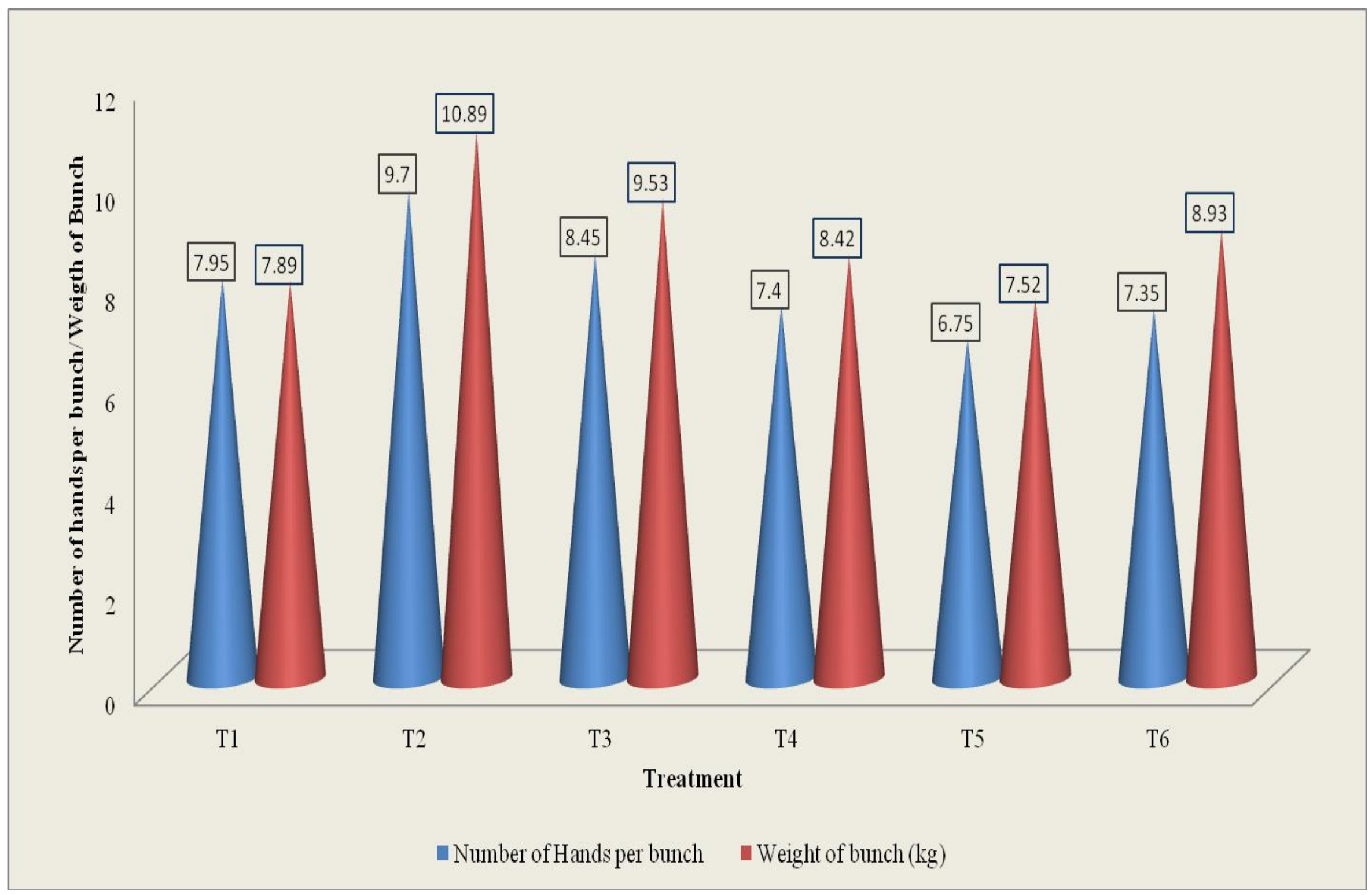


Fig.3 Effect of INM on internodal length of bunch in banana $c v$. Rajapuri (AAB)

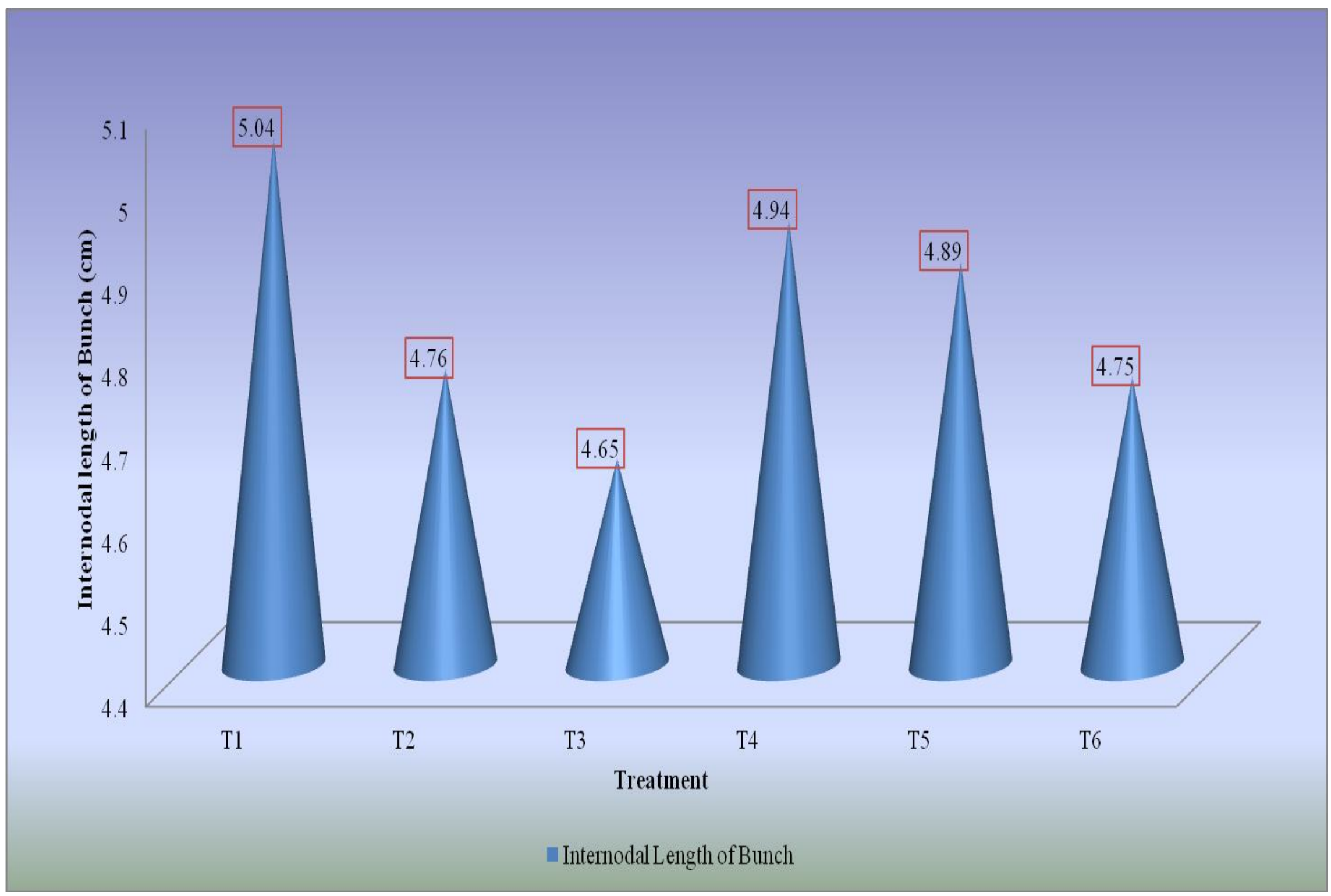


Fig.4 Effect of INM on Average weight of finger in banana $c v$. Rajapuri (AAB)

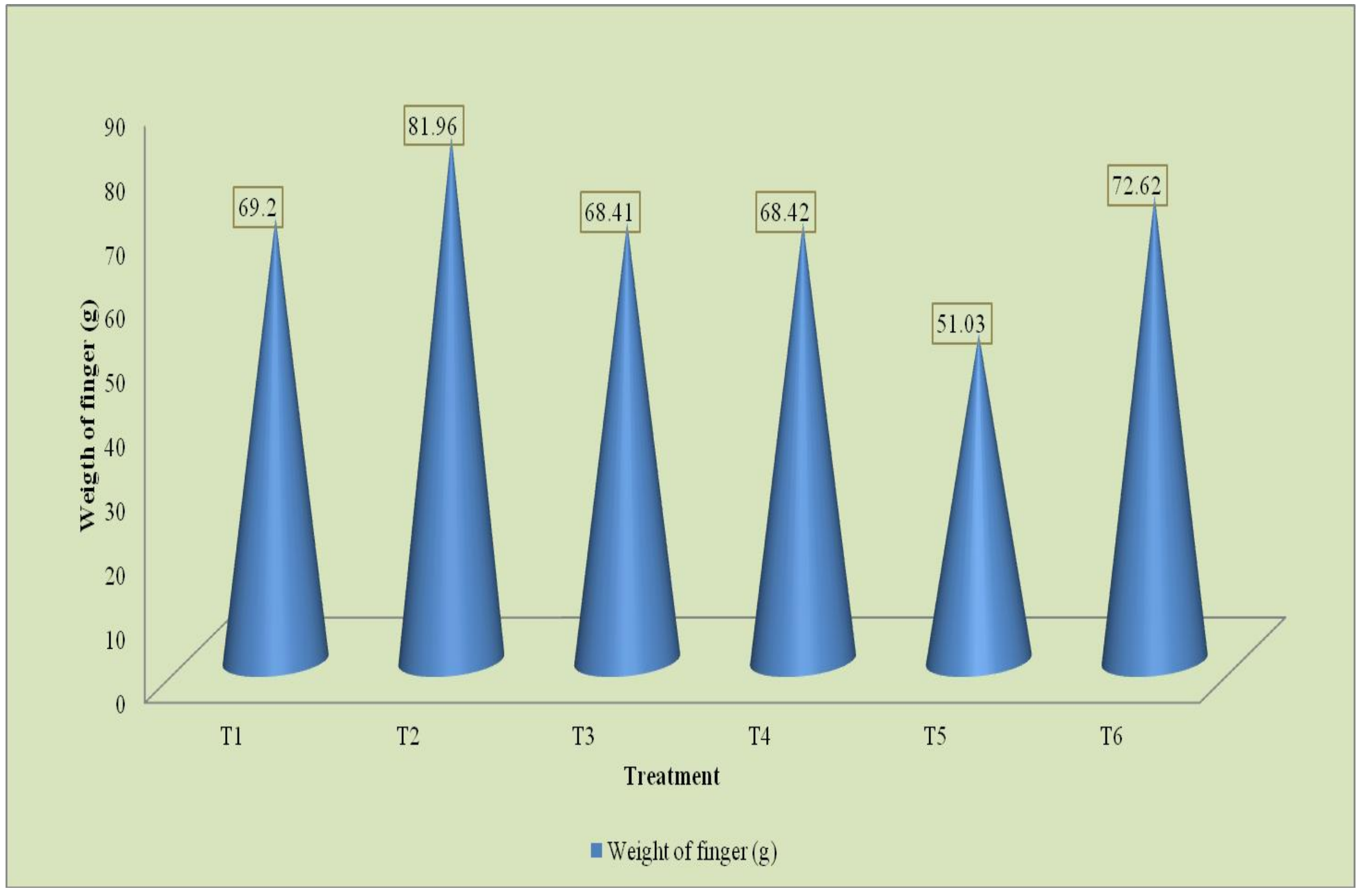


Fig.5 Effect of INM on number of finger per hand in banana $c v$. Rajapuri (AAB)

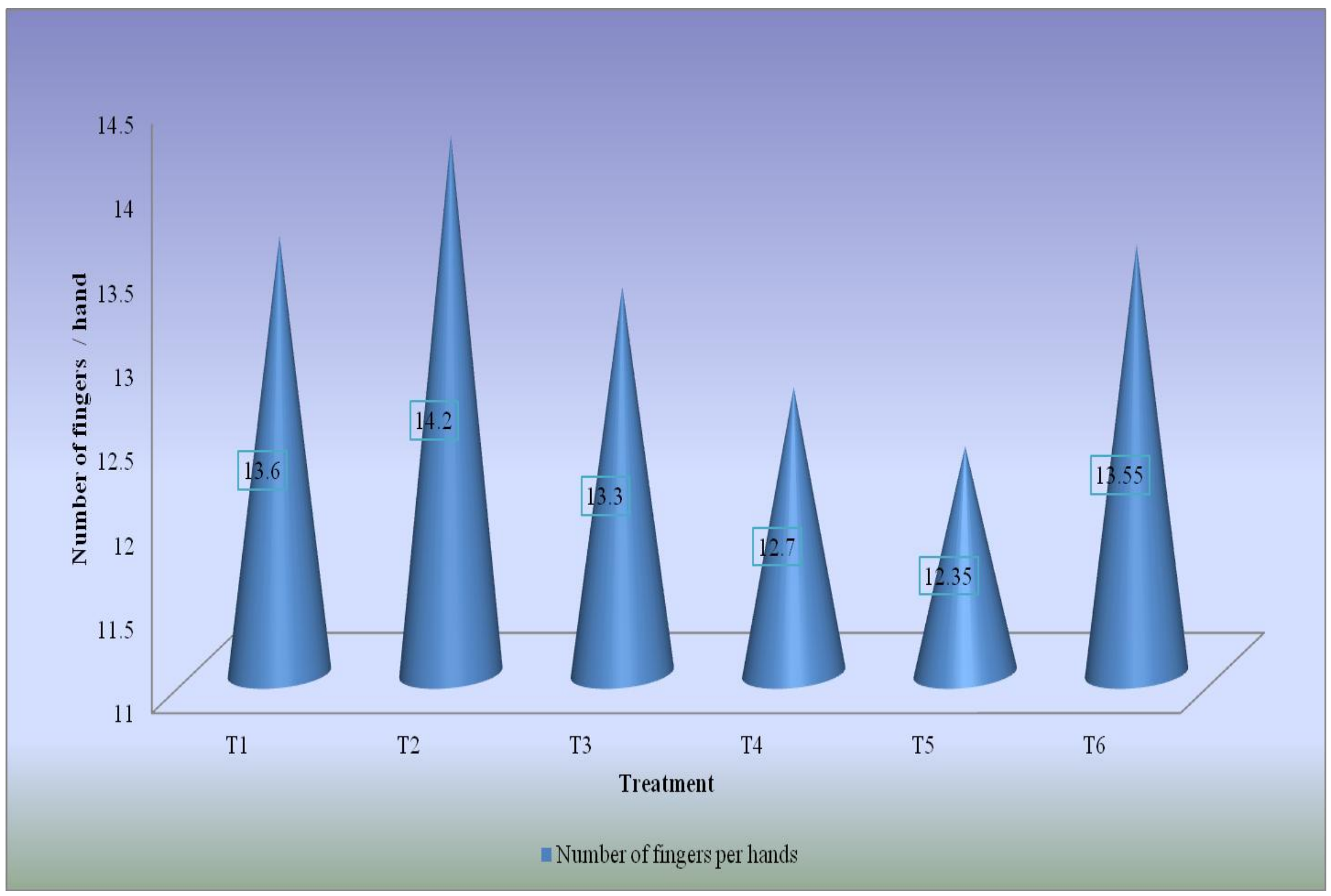


Fig.6 Effect of INM on length and girth of finger in banana $c v$. Rajapuri (AAB)

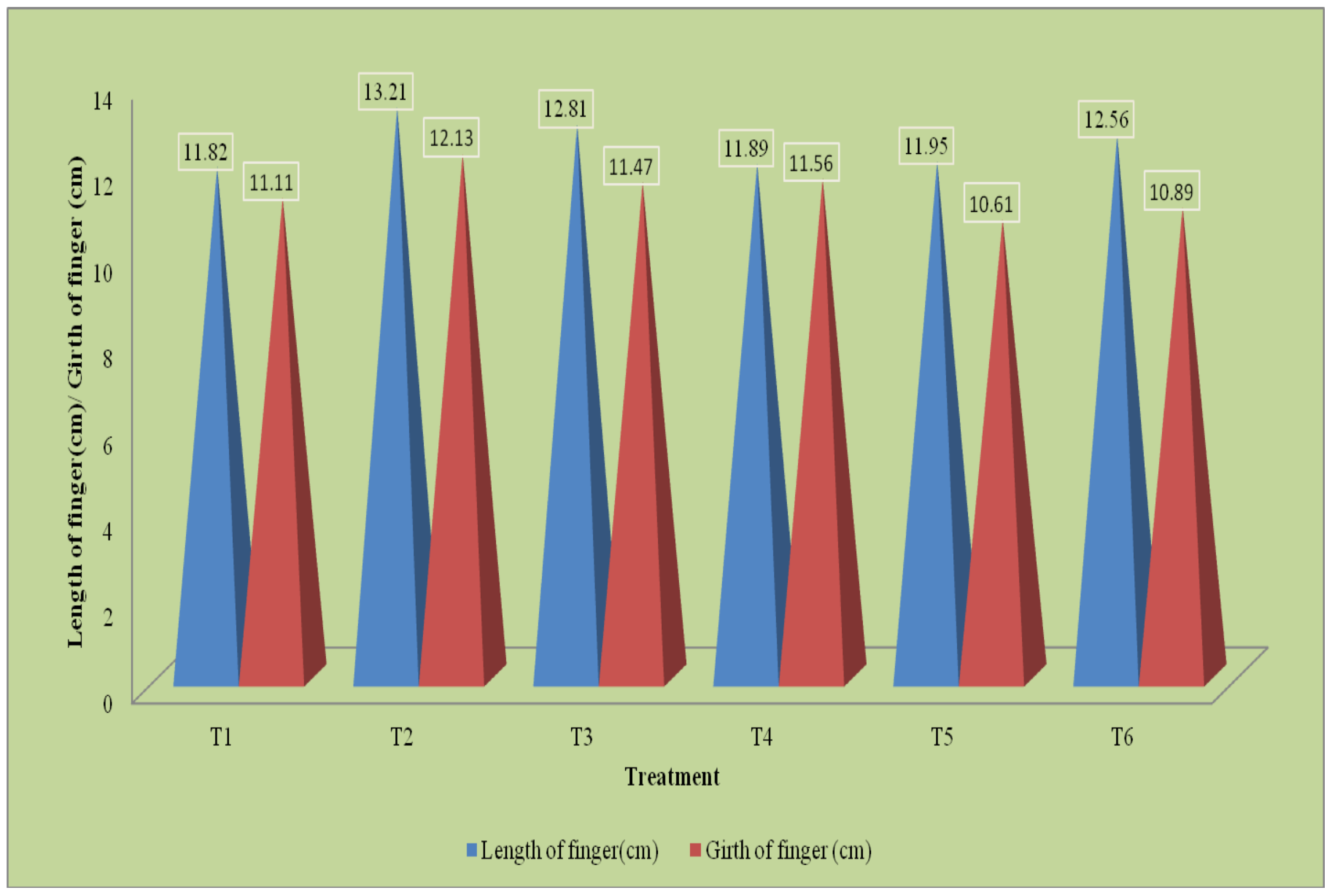


Fig.7 Effect of INM on Total Yield of banana $c v$. Rajapuri (AAB)

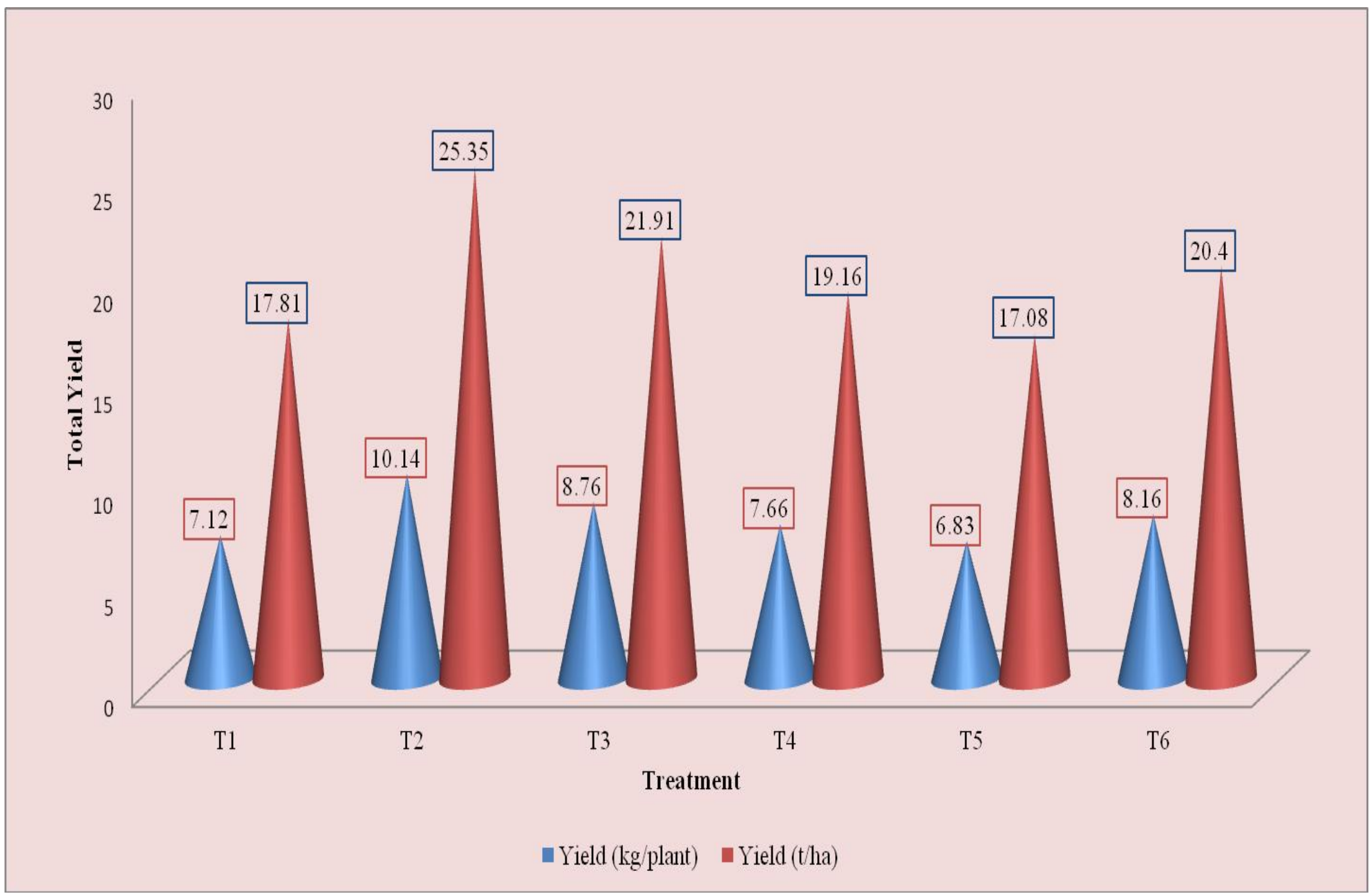


Table.1 Effect of INM on bunch characters of banana cv. Rajapuri (AAB)

\begin{tabular}{|c|c|c|c|c|c|}
\hline \multicolumn{2}{|c|}{ Treatment } & \multirow{2}{*}{$\begin{array}{l}\text { Length of } \\
\text { bunch } \\
\text { (cm) }\end{array}$} & \multirow{2}{*}{$\begin{array}{l}\text { No. of } \\
\text { hands } \\
\text { per } \\
\text { bunch } \\
7.95\end{array}$} & \multirow{2}{*}{$\begin{array}{l}\text { Weight } \\
\text { of } \\
\text { bunch } \\
\text { (kg) } \\
7.89\end{array}$} & \multirow{2}{*}{$\begin{array}{l}\text { Internodal } \\
\text { length of } \\
\text { bunch (cm) }\end{array}$} \\
\hline $\mathbf{T}_{1}$ & $\begin{array}{l}\text { RDF } 100 \% \text { (200:100:300 g N:P } \mathrm{O}_{5}: \mathrm{K}_{2} \mathrm{O}+20 \\
\text { kg FYM per plant) }\end{array}$ & & & & \\
\hline $\mathbf{T}_{2}$ & $\begin{array}{l}\text { RDF } 100 \%\left(200: 100: 300 \text { g N:P } \mathrm{P}_{2}: \mathrm{K}_{2} \mathrm{O}+20\right. \\
\text { kg FYM per plant })+\mathrm{PSB}(20 \mathrm{~g})+A z o(20 \mathrm{~g})\end{array}$ & 59.40 & 9.70 & 10.89 & 4.76 \\
\hline $\mathbf{T}_{3}$ & $\mathrm{RDF} 75 \%+25 \% \mathrm{~K}_{2} \mathrm{O}$ through organic source & 53.00 & 8.45 & 9.53 & 4.65 \\
\hline $\mathbf{T}_{4}$ & RDF $50 \%+50 \% \mathrm{~K}_{2} \mathrm{O}$ through organic source & 52.92 & 7.40 & 8.42 & 4.94 \\
\hline $\mathbf{T}_{5}$ & $\mathrm{RDF} 25 \%+75 \% \mathrm{~K}_{2} \mathrm{O}$ through organic source & 52.95 & 6.75 & 7.52 & 4.89 \\
\hline$T_{6}$ & $100 \% \mathrm{~K}_{2} \mathrm{O}$ through organic source & 54.85 & 7.35 & 8.93 & 4.75 \\
\hline & S. Em. \pm & 0.31 & 0.12 & 0.06 & 0.08 \\
\hline & C.D. at $5 \%$ & 0.94 & 0.42 & 0.19 & 0.25 \\
\hline
\end{tabular}

INM = Integrated Nutrient Management

Azo $=$ Azospirillum

PSB $=$ Phosphate Solubilizing Bacteria

$\mathrm{RDF}=$ Recommended Dose of Fertilizer

For Tissue Culture Plant RDF (200:100:300 g N: $\mathrm{P}_{2} \mathrm{O}_{5}: \mathrm{K}_{2} \mathrm{O}+20 \mathrm{~kg}$ FYM per plant)

FYM = Farm Yard Manure

Table.2 Effect of INM on finger characters of banana cv. Rajapuri (AAB)

\begin{tabular}{|c|c|c|c|c|c|}
\hline \multicolumn{2}{|c|}{ Treatment } & \multirow{2}{*}{$\begin{array}{c}\begin{array}{c}\text { No.of } \\
\text { fingers } \\
\text { per } \\
\text { hands }\end{array} \\
13.60\end{array}$} & \multirow{2}{*}{$\begin{array}{c}\begin{array}{c}\text { Length } \\
\text { of finger } \\
\text { (cm) }\end{array} \\
11.82\end{array}$} & \multirow{2}{*}{$\begin{array}{c}\text { Girth of } \\
\text { fingers } \\
\text { (cm) }\end{array}$} & \multirow{2}{*}{$\begin{array}{c}\begin{array}{c}\text { Weight } \\
\text { of finger } \\
(\mathrm{g})\end{array} \\
69.2\end{array}$} \\
\hline$T_{1}$ & $\begin{array}{l}\text { RDF } 100 \%\left(200: 100: 300 \mathrm{~g} \mathrm{~N}: \mathrm{P}_{2} \mathrm{O}_{5}\right. \\
: \mathrm{K}_{2} \mathrm{O}+20 \mathrm{~kg} \text { FYM per plant) }\end{array}$ & & & & \\
\hline$\overline{T_{2}}$ & $\begin{array}{l}\text { RDF } 100 \%\left(200: 100: 300 \text { g N:P } \mathrm{P}_{2} \mathrm{O}_{5}:\right. \\
\left.\mathrm{K}_{2} \mathrm{O}+20 \mathrm{~kg} \text { FYM per plant }\right)+\mathrm{PSB} \\
(20 \mathrm{~g})+A z o(20 \mathrm{~g})\end{array}$ & 14.20 & 13.21 & 12.13 & 81.96 \\
\hline$\overline{T_{3}}$ & $\begin{array}{l}\text { RDF } 75 \%+25 \% \mathrm{~K}_{2} \mathrm{O} \text { through } \\
\text { organic source }\end{array}$ & 13.30 & 12.81 & 11.47 & 68.41 \\
\hline $\mathrm{T}_{4}$ & $\begin{array}{l}\text { RDF } 50 \%+50 \% \mathrm{~K}_{2} \mathrm{O} \text { through } \\
\text { organic source }\end{array}$ & 12.70 & 11.89 & 11.56 & 68.42 \\
\hline$\overline{T_{5}}$ & $\begin{array}{l}\mathrm{RDF} 25 \%+75 \% \mathrm{~K}_{2} \mathrm{O} \text { through } \\
\text { organic source }\end{array}$ & 12.35 & 11.95 & 10.61 & 51.03 \\
\hline$T_{6}$ & $100 \% \mathrm{~K}_{2} \mathrm{O}$ through organic source & 13.55 & 12.56 & 10.89 & 72.62 \\
\hline & S. Em. \pm & 0.10 & 0.10 & 0.11 & 0.38 \\
\hline & C.D. at $5 \%$ & 0.31 & 0.31 & 0.33 & 1.15 \\
\hline
\end{tabular}

$\mathrm{INM}=$ Integrated Nutrient Management

Azo $=$ Azospirillum

PSB $=$ Phosphate Solubilizing Bacteria

$\mathrm{RDF}=$ Recommended dose of Fertilizer

For Tissue Culture Plant RDF (200:100:300 g N: $\mathrm{P}_{2} \mathrm{O}_{5}: \mathrm{K}_{2} \mathrm{O}+20 \mathrm{~kg}$ FYM per plant)

$\mathrm{FYM}=$ Farm Yard Manure 
Table.3 Effect of INM on yield and yield parameters of banana cv Rajapuri (AAB)

\begin{tabular}{|c|c|c|c|}
\hline & Treatment & Yield & Yield (t/ha) \\
\hline$T_{1}$ & $\begin{array}{l}\text { RDF } 100 \% \text { (200:100:300 g N:P } \mathrm{P}_{2} \mathrm{O}_{5}: \mathrm{K}_{2} \mathrm{O}+20 \mathrm{~kg} \\
\text { FYM per plant) }\end{array}$ & 7.12 & 17.81 \\
\hline $\mathbf{T}_{2}$ & $\begin{array}{l}\text { RDF } 100 \%\left(200: 100: 300 \mathrm{~g} \mathrm{~N}: \mathrm{P}_{2} \mathrm{O}_{5}: \mathrm{K}_{2} \mathrm{O}+20 \mathrm{~kg}\right. \\
\text { FYM per plant })+\mathrm{PSB}(20 \mathrm{~g})+A z o(20 \mathrm{~g})\end{array}$ & 10.14 & 25.35 \\
\hline$\underline{T_{3}}$ & RDF $75 \%+25 \% \mathrm{~K}_{2} \mathrm{O}$ through organic source & 8.76 & 21.91 \\
\hline$\overline{T_{4}}$ & RDF $50 \%+50 \% \mathrm{~K}_{2} \mathrm{O}$ through organic source & 7.66 & 19.16 \\
\hline $\mathrm{T}_{5}$ & $\mathrm{RDF} 25 \%+75 \% \mathrm{~K}_{2} \mathrm{O}$ through organic source & 6.83 & 17.08 \\
\hline$T_{6}$ & $100 \% \mathrm{~K}_{2} \mathrm{O}$ through organic source & 8.16 & 20.40 \\
\hline & $\begin{array}{c}\text { S. Em. } \pm \\
\end{array}$ & 1.23 & 2.48 \\
\hline & C.D. at 5\% & 3.70 & 7.49 \\
\hline
\end{tabular}

$\mathrm{INM}=$ Integrated Nutrient Management

Azo $=$ Azospirillum

$\mathrm{PSB}=$ Phosphate Solubilizing Bacteria

RDF $=$ Recommended dose of Fertilizer

For Tissue Culture Plant RDF (200:100:300 g N: $\mathrm{P}_{2} \mathrm{O}_{5}: \mathrm{K}_{2} \mathrm{O}+20 \mathrm{~kg}$ FYM per plant)

FYM = Farm Yard Manure

The maximum yield $(10.14 \mathrm{~kg} / \mathrm{ha})$ was obtained in treatment $\left(\mathrm{T}_{2}\right)$, where, the plants were supplied with RDF 100\% (200:100:300 g NPK + 20 kg FYM per plant) + PSB (20 g) + Azospirillum (20 g), which was followed by $\mathrm{T}_{3}(8.76 \mathrm{~kg} / \mathrm{plant}), \mathrm{T}_{6}(8.16 \mathrm{~kg} / \mathrm{plant}), \mathrm{T}_{4}(7.66$ $\mathrm{kg} / \mathrm{plant})$ and $\mathrm{T}_{1}(7.12 \mathrm{~kg} / \mathrm{plant})$. While, the minimum yield $(6.83 \mathrm{~kg} / \mathrm{plant})$ was obtained in $\left(T_{5}\right)$.

The effect of INM on total yield per hectare of banana cv. Rajapuri indicated a significant difference among the different treatments and the data on yield are presented in Table 3 . The maximum yield $(25.35 \mathrm{t} / \mathrm{ha})$ was obtained in treatment $\left(\mathrm{T}_{2}\right)$, where, the plants were provided with, RDF 100\% (200:100:300 g NPK + 20 kg FYM per plant) + PSB (20 g) + Azospirillum (20 g), which was followed by $\mathrm{T}_{3}$ (21.91 t/ha), $\mathrm{T}_{6}(20.40 \mathrm{t} / \mathrm{ha})$ and $\mathrm{T}_{4}$ (19.16t/ha). While, the minimum yield (17.08 $\mathrm{t} / \mathrm{ha}$ ) was obtained in $\left(\mathrm{T}_{5}\right)$, which was on par with $\mathrm{T}_{1}(17.81 \mathrm{t} / \mathrm{ha})$.

The balanced nutrients might have contributed for higher number of fingers per hand, higher average weight of fingers and more number of hands and bunch resulted into economic yield (Fig. 1, 2, and 3). This result in conformity with the findings of Pathak et al., (1992), Natesh et al., (1993), Raju (1996) and Nalina (1999). Increase in yield attributes could be due to the increase in morphological traits such as plant height, girth, number of functional leaves, leaf area index, faster rate of leaf production and also higher nutrient uptake by the plants. Increase in number of leaves might have enhanced the photosynthetic activity resulting in higher accumulation of carbohydrates. Relatively higher carbohydrates could have promoted the growth rate and in turn increased bunch weight. This was in accordance with the results of Chezhiyen et al., (1999) in banana. The increase in finger weight (Fig. 4) might be due to the increase in production of promoting endogenous and enhancement of nutrient uptake in addition to the role of nitrogen on productivity of banana plants (Nijjar,1985). Hence, factor that stimulates higher finger production and favours better finger (Fig. 5 and 6) development leads to 
better bunch weight. The maximum yield $(25.35 \mathrm{t} / \mathrm{ha})$ was obtained in treatment $\left(\mathrm{T}_{2}\right)$ where, the plants were provided with, RDF 100\% (200:100:300 g NPK + 20 kg FYM per plant $)+$ PSB (20 g) + Azospirillum (20 g), which was followed by $\mathrm{T}_{3}(21.91 \mathrm{t} / \mathrm{ha}), \mathrm{T}_{6}$ (20.40 t/ha) and $T_{4}(19.16 \mathrm{t} / \mathrm{ha})$. Whereas, the minimum yield (17.08 t/ha) was obtained in $\left(\mathrm{T}_{5}\right)$, which was on par with $\mathrm{T}_{1}(17.81 \mathrm{t} / \mathrm{ha})$ (Fig. 7). In general, the number of hands in a bunch normally ranges from 6 to 9 in banana cv. Rajapuri. There was a reduction in the number of hands, weight, length and girth of fingers under RDF $25 \%+75 \%, \mathrm{~N}$ and $\mathrm{P}$ through organic sources with lower level of nutrients (25\% RDF). Higher yield response owing to application of organics ascribed to improved physical, chemical and biological properties of soil resulting in better supply of plant nutrients, which in turn led to the good crop growth and yield. Humus substance present in organic product could have mobilized the reserve food material to the sink through increased activity of hydrolyzing and oxidizing enzymes. These products would help the better availability and utilization of nutrients. All these positive effect might have facilitated quick mobilization and availability of nutrients that would aid in increased plant height, number of leaves, leaf area, leaf area index and photosynthetic rate.

This in turn could have assisted for the increased yield of banana. This is in confirmation with the findings of Kuttimani et al., (2013) in banana. The applied N, P, K and biofertilizers were utilized efficiently by the plant, which resulted in producing maximum photosynthates in terms of high biomass and translocating the assimilated material to the developing sink resulting in heavier weight of bunch. Nitrogen is the chief constituent of chlorophyll. Protein and amino acids, the synthesis of which is accelerated through increased supply of Nitrogen (Patil and Shinde, 2013).
Hence, the integrated nutrient management practice of $100 \%$ recommended dose of fertilizer combined with organic manures and biofertilizers in banana crop has been found to be an ideal option to improve the yield besides being economically competitive and productive under the soil and climatic conditions of arid zone of Karnataka.

\section{Acknowledgement}

I would like to thank the Chairman of my Advisory Committee Dr. Kulapati Hipparagi, Professor and Head, Dept. of fruit Science University of Horticultural Sciences, Bagalkot for excellent guidance and affection showing throughout the course of the investigation. I wish to express my profound indebtedness and heartfelt thanks to Dr. I. B. Biradar Professor of Agronomy MHREC, Bagalkot, Dr. S.N. Patil Assistant Professor Dept. of Fruit Science $\mathrm{COH}$, Bagalkot, Dr. Suma, R. Assistant Professor (SS \& AC), $\mathrm{COH}$, Bagalkot, Dr. Mallikarjun Awati Assistant Professor (Crop Physiology) COH, Bagalkot for serving as members of my Advisory Committee, under whose edifying counsels and salutary advices my efforts assumed newer shape. I must confess that, it had been a privilege for me to be associated with them during my master's degree programme. I express my deep sense of gratitude and affection to my parents Sri. Shivanand, and Smt. Meenaxi, S. Pattar, brothers Praveen Arjun, Naveen Sisters Veena, Archana, Nandini, and all my relatives for their boundless love, unflagging interest and constant encouragement, put confidence in me to reach this level.

\section{References}

Chezhiyan, N., Balasubramani, P., Vijulan Harris, C., Aanathan, M., 1999. Effect of inorganic and biofertilizers on growth and yield of hill banana var. 
Virupakshi. South Indian Hort., 47 (1-6) 161.

Jithendra Singh, 2014. Basic Horticulture, Kalyani Publishers, pp 209-210.

Kuttimani, R. and Velayudam. K. and Somasundarm, E., 2013. Growth and yield parameters and nutrient uptake of banana as influenced by integrated nutrient management practices. International J. Recent Sci. Res., vol.4, Issue, 5, pp 680-686.

Nalina, L., 1999. Studied on high density planting in banana cv. Robusta (AAA). M.Sc. (Hort.) Thesis. TNAU, Coimbatore.

Natesh, B. B., Aravind Akshan, M. and Vastalakumari, P. K., 1993. Effect of split application of fertilizers in banana, Musa AAB 'Nendran'. South Indian Hort., 41 (2):67-73.
Nijjar, G.S., 1985. Banana- role of nitrogen on yield. In: Nutrition of fruit trees. Usha, R (Ed), Kalyani Publishers, New Delhi, India, pp.306-308.

Pathak, R. A., Singh, B. V. and Ojiha, C. M., 1992. Studies on the combination effect of nitrogen and potash on the growth and yield of banana cv. Harichal. National Symposium on Banana Abstracts, 38.

Patil, V. K. and Shinde, B.N., 2013. Studies on integrated nutrient management on growth and yield of banana $\mathrm{cv}$. Ardhapuri (Musa AAA). J. Hort. Forest. vol., 5 (9), pp. 130-138.

Raju Besagarahalli, 1996. Micropropagation and nutritional studies of tissue cultured banana var. Grand Naine, Ph.D. (Hort.) thesis submitted to UAS, Bangalore.

\section{How to cite this article:}

Suhasini S. Pattar, Kulapati Hipparagi, I.B. Biradar, S.N. Patil, R. Suma, Mallikarjun Awati and Arunkumar Kamble. 2018. Effect of Integrated Nutrient Management on Yield Parameters of Banana cv. Rajapuri. Int.J.Curr.Microbiol.App.Sci. 7(01): 2986-3000. doi: https://doi.org/10.20546/ijcmas.2018.701.356 